\title{
The Art of Seeing Like a State: State-Building in Afghanistan, the Congo, and Beyond
}

\author{
Christopher J. Coyne and Adam Pellillo*
}

\begin{abstract}
This paper considers the implications of James Scott's Seeing L ike a State (1998) and The A rt of N ot Being $G$ overned (2009) for state-building efforts in Afghanistan and the Democratic Republic of the Congo (D RC). In Seing Like a State, Scott warns of the problems associated with top-down planning efforts to improve the human condition. In The A rt of $\mathrm{N}$ ot Being $\mathrm{G}$ overned, Scott discusses the 'art' of state avoidance and self-governance. These works have important insights for contemporary statebuilding processes and we explore some of the applications in the context of Afghanistan and the D RC. We conclude with a discussion of the implications for current and future state-building efforts.
\end{abstract}

JEL Codes: B52, B53, 02

Keywords: high modernism, métis, state building, weak states, failed states, state capacity, Afghanistan, D emocratic Republic of the Congo

\footnotetext{
* Christopher J. Coyne (ccoyne3@ gmu.edu), George Mason University, D epartment of Economics, Fairfax, VA 22030. Adam Pellillo (adam.pellillo@ mail.wvu.edu), West Virginia University, Department of Economics, Morgantown, WV 26506-6025.
} 


\section{Introduction}

In Seeing L ike a State, James Scott (1998) explores what he calls "high modernism," the "... strong, one might even say muscle-bound, version of the beliefs in scientific and technical progress that were associated with industrialization in Western Europe and in North America from roughly 1830 until World War I" (89). At the basis of high modernism is the "... supreme self-confidence about continued linear progress, the development of scientific and technical knowledge, the expansion of production, the rational design of social order, the growing satisfaction of human needs, and, not least, an increasing control over nature" (89).

Scott applies the concept of high modernism to a variety of state-led efforts intended to improve the human condition. In doing so, he identifies three elements that have led to significant human tragedy despite good intentions to make people better off. The first element is the desire to achieve an administrative ordering of nature and society. The second element is the willingness of the modern state to use power to achieve the desired ordering. The final element is the presence of a weak civil society that is unable to resist the use of power by the state. The many failures of central planning in the twentieth century- e.g. Soviet collectivization, China's Great Leap Forward, compulsory 'villagization' in Tanzania, planned 'scientific cities,' etc.- Scott argues, are due to an unfortunate confluence of these three elements.

In his subsequent book, The A rt of $\mathrm{N}$ ot Being Governed, Scott (2009) focuses on the populations residing in Zomia- a mountainous region in Southeast Asia- which was one of the largest remaining areas that had not been integrated into a formal nation state. The standard view of the populations living in this mountainous region, commonly referred to as "hill people," is that they were remnants of the pre-state period and represented an uncivilized form of living. In contrast, those who moved into the lowlands and became part of the state system were viewed as civilized 
and developed. The novel contribution of Scott's book is to turn this standard view on its head. In contrast to the view that the populations residing in Zomia were primitive leftovers of the pre-state period, Scott argues that those living in the highlands consciously chose to live outside the reach of the state. Given the possibility of being subjected to predatory behaviors by states-including conscription, slavery, excessive taxes, forced labor, and war- people made the choice to move into the hills as an act of state avoidance. The resistance of Zomians to the state, while evident for hundreds of years prior, was particularly manifest in the post-World War II period, "when Zomia became the site of secessionist movements, indigenous rights struggles, millennial rebellions, regionalist agitation, and armed opposition to lowland states" (Scott 2009: 19).

These insights have implications not only for our understanding of the mountainous regions of Southeast Asia, but also for how we think about other societies whose states and governance mechanisms differ in form and structure from Western nation-states. Although Scott is focused on Zomia in The A rt of $\mathrm{N}$ ot Being $\mathrm{G}$ overned, a number of parallels can be drawn between Zomia and what are commonly categorized as "weak," "fragile," "failed," and "collapsed" states. ${ }^{1}$ These states typically lack a monopoly on the legitimate use of force across their entire territories, much like the lowland states of Southeast Asia in the time period considered by Scott. Further, these states have difficulty raising revenues and providing what are often considered 'public goods' such as security, education, basic infrastructure, etc. Because of their deficiencies on a number of margins, countries with weak, fragile, failed, or collapsed states are typically viewed as requiring institutional reform. State-building processes- e.g. the development of new constitutions, the holding of elections, the employment of disarmament, demobilization, and reintegration [DDR] programs, the training of military and police forces, etc. - that are assisted by those in the 'international community' - e.g., the

\footnotetext{
${ }^{1}$ It is important to note, however, that the contexts under consideration in this paper are quite different than those in Zomia, temporally but also culturally, historically, and politically.
} 
UN, World Bank, IMF, Asian D evelopment Bank, NGOs, etc-are typically oriented around the development and expansion of state institutions across the entire geographic country.

Y et there are a number of factors that must be appreciated when considering state-building efforts and Scott's works provide many insights into the myriad challenges in these efforts. First, the state institutions- e.g. constitutions, legal systems, militaries, etc.- that are developed may not sufficiently constrain state political actors from engaging in many of the predatory actions identified by Scott in The A rt of $\mathrm{N}$ ot Being $\mathrm{G}$ overned- e.g. excessive taxes, human rights abuses, war, etc.

Second, in many countries where the state does not have complete territorial control (particularly in Afghanistan and the Democratic Republic of the Congo, but also in countries like Colombia or Somalia), there are sub-national non-state political actors who maintain a considerable amount of power and control over specific regions within the country. Efforts to develop and expand state institutions will be costly because of the need to co-opt or coerce- e.g. through diplomacy, political/financial incentives, legal proceedings, or military/ police force- non-state political actors in order to make the state institutions operable. In some cases, even officials of the state may resist the development of state institutions since strong states are associated with strong institutional constraints- e.g. checks and balances. State political actors may reject such constraints in order to maintain their power and discretion. ${ }^{2}$

Lastly, in The A rt of $\mathrm{N}$ ot Being $\mathrm{G}$ overned, Scott shows there is a complex 'art' to avoiding the formal state while acting orderly in a stateless society. Efforts to expand and develop state institutions overlook civil society and customary governance organizations which can fill the void in

2 For instance, political authorities in the Afghanistan and the Democratic Republic of the Congo may be loath to strengthen state institutions because the payoffs they receive from weaker state institutions are higher than those under strong state institutions. See Stearns (2011a, b) in the context of the Democratic Republic of the Congo. Also, as noted by Chowdhury and Krebs (2010), "because it benefits from foreign troops, money, and materiel, the Afghan government has little reason to develop the strong institutions it needs to extract resources and project power." 
the absence of a functional state. ${ }^{3}$ While these organizations lack the reach and resources of a largerscale state, they play crucial roles in peace-building efforts in these countries and this capacity for local self-governance has implications for which specific state institutions are developed. ${ }^{4}$ Moreover, despite the potential limits of these local forms of governance, it cannot be assumed that a nationstate is a preferable state of affairs (see Coyne 2006, 2007). Precisely because it has a greater reach and access to more resources a dysfunctional nation state can cause significant harms to ordinary people.

The purpose of this paper is to explore some of the connections between Scott's two books in order to address state-building efforts in Afghanistan and the Democratic Republic of the Congo (DRC). We focus on these two countries because they are currently experiencing transformative state-building efforts with assistance by a variety of actors in the 'international community.' Thousands of troops have been deployed to these countries (NATO-ISAF in Afghanistan and MO NUC/ MO NUSCO in the D emocratic Republic of the Congo) and a significant amount of time, resources, and effort has been invested into state-building in both of these countries. Yet in both cases state-building processes have suffered from significant problems and setbacks. Some statebuilding efforts have been entirely contradictory to one another-e.g. attempts at improving and expanding state institutions while simultaneously supporting local 'power brokers' and militias which undermine the state institutions- while many reconstruction projects have been mired by waste, inefficiency, and perverse incentives, not to mention destruction by insurgents and rebels.

\footnotetext{
${ }^{3}$ In addition to overlooking these organizations, efforts to expand state institutions over the entire territory overlook forms of autonomous rule like Somaliland in Somalia.

${ }^{4}$ For instance, instead of focusing on holding elections, the international community could allocate greater resources towards assisting the development of local peace-building institutions and professionalizing the security sector.
} 
Afghanistan and the DRC face considerable challenges, especially with regards to governance and ensuring security. ${ }^{5}$ Scott's works highlight two key challenges associated with statebuilding processes in these countries: (1) the lack of alignment between institutional structures and local preferences, and (2) political incentives and the resistance of state and non-state political actors and citizens to the expansion of state institutions over the entire country. As is well-evident, preventing and resolving conflict in 'post-conflict' situations "... entails the complex political task of addressing the root causes of the conflict" (del Castillo 2008: 15, emphasis added). Addressing political incentives at the national, regional, and local levels is an incredibly complex task, one that often entails the employment of a range of diplomatic, legal, political, military, and police tools. As we discuss below, it is precisely because of this complexity that these efforts run the risk of suffering from the 'high modernism' that Scott warned against.

We proceed as follows. The next section draws on concepts from Seeing L ike a State and The A rt of $\mathrm{N}$ ot Being $\mathrm{G}$ overned to discuss institutions and institutional 'stickiness' in the context of statebuilding. Section 3 highlights the 'high modernism' of state-building efforts in Afghanistan and the D RC, while Section 4 discusses why these efforts will continue to be costly without a reorientation of state-building processes. Section 5 concludes.

\section{Métis and Institutional Stickiness}

In Seeing L ike a State, Scott emphasizes the crucial role played by inarticulate knowledge. In order to do so, he draws on the Greek concept of métis, which refers to "... a wide array of practical skills and acquired intelligence in responding to a constantly changing natural and human environment" (1999:

\footnotetext{
${ }^{5}$ See also Del Castillo (2008).
} 
313). The essence of métis is knowing when to apply context-specific and inarticulate knowledge to concrete and actual situations. If the information written in books represents objective data that is out there for all to see, then the concept of métis involves knowing when to "... throw away the book and improvise" (1999: 314). Scott concludes that many state-led efforts to improve the human condition have failed precisely because planners neglected the important role played by métis. Without knowledge of what worked and what didn't, planners implemented top-down projects that resulted in widespread failures.

Recognizing the importance of métis- in addition to the importance of local incentives and preferences- provides insight into why state-building processes are often so challenging and complex. ${ }^{6}$ Efforts to reform institutions, develop infrastructure, promote local security, etc. will be less successful when they are not aligned with local preferences, incentives, and the established knowledge of how to get things done.

To provide an example, consider counterinsurgency efforts where the military's operating principles are not typically centered on the role and importance of métis, counterinsurgency operations may very well be less effective. Lyall and Wilson (2009) argue that modern military forces are not structured in a way that is conducive to gathering local information, which explains why the success rate of counterinsurgencies has declined over time. They argue that "faced with "information starvation,' mechanized forces often inadvertently fuel, rather than suppress, insurgencies" (2009: 68). Similarly, if reconstruction projects or the distribution of goods and services are not aligned

${ }^{6}$ A lack of attention to métis in state-building efforts is closely related to what Kalyvas (2006: 39) identifies as 'urban bias,' which in the context of civil wars is the "... more general tendency to interpret civil wars acontextually and in an exclusively top-down manner." The likely causes of urban bias, Kalyvas argues, are prejudice and costly information. The former is a result of a "... long tradition of interpreting rural violence as a manifestation of primitivism" (2006: 40) whereas the latter is likely due to difficulties in accessing the countryside or challenging terrain (e.g. upland Southeast Asia, Afghanistan, DR Congo, etc.) in addition to many other factors. Urban bias is particularly problematic in peacebuilding efforts, for instance, because "... it distorts data and conceptualizations of civil war dynamics; it tends to privilege written sources, 'top-down' perspectives, ideological or normative motivations of participants, and fixed, unchanging identities and choices over oral sources, 'bottom-up' perspectives, nonideological motivations of participants, and fluid identities and choices" (2006: 42) 
with the preferences of citizens and métis, they will likely be inefficient and represent a misallocation of resources. Citizens may not value particular reconstruction projects or goods/ services as much as state-builders think they will value them. If this is the case, then the projects will be 'underutilized' from the perspective of the state-builder. ${ }^{7}$

The issue of alignment is important because of the enforcement costs associated with various state-building alternatives. When there is a misalignment between institutions, reconstruction projects, etc. and the underlying métis, ensuring that state-building reforms will 'stick' will require high enforcement costs. For instance, if informal norms guiding the behavior of citizens or the incentives of local militia members or warlords are at odds with formal institutions, actually getting the formal institutions to operate the way they were intended will require continual enforcement and force. This point is captured by the well-known adage 'A free society works best when the need for police is least.' What this means is that a free society works well when citizens act in a manner that respects the basic rules of the game making the need for formal enforcement minimal. This enforcement may take the form of diplomacy, financial or political incentives- e.g. co-opting warlords- legal sanctions, or military/ police force. Ending local violence requires shaping incentives and constraints in such a way that political actors will not engage in expropriation of assets, human rights abuses, etc. If the existing métis is in opposition to these goals, enforcement costs will be high.

Boettke, Coyne, and Leeson (2008: 344) provide insight into the connection between métis and 'institutional stickiness,' which refers to the likelihood that institutions will operate as intended. Figure 1 illustrates this relationship.

\footnotetext{
${ }^{7}$ On the issue of economic calculation and foreign aid, see Skarbek and Leeson (2009) and Williamson (2010).
} 


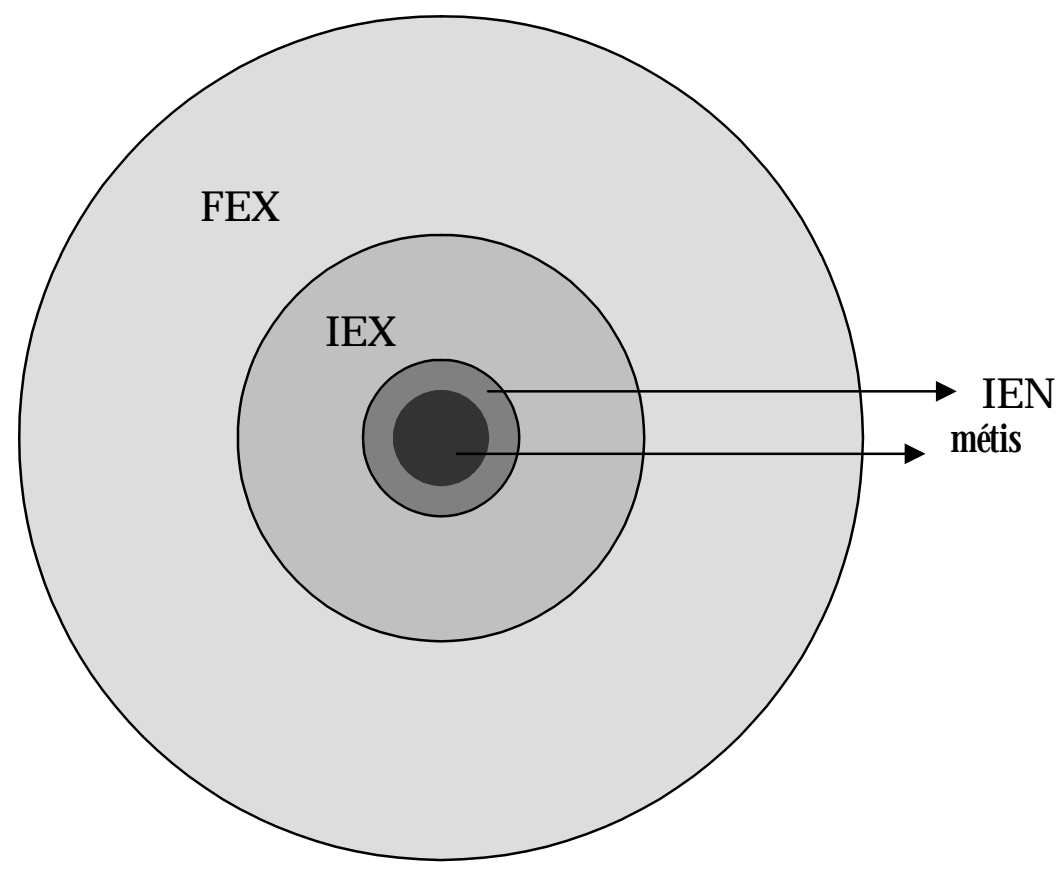

Figure 1: Institutional Stickiness

At the core of Figure 1 is métis which serves as the 'glue' which allows institutions to operate as intended. ${ }^{8}$ Boettke, Coyne, and Leeson (2008) provide the following categories of institutions, which can be understood as the rules of the game, as illustrated in Figure 1.

1. Indigenously-introduced endogenous (IEN) institutions - IEN institutions are those institutions which emerge over time. These institutions develop as a byproduct of the interactions of numerous individuals-e.g. markets [the bazaar], social norms, cultural values, tribal, clan, or village-based networks and organizations, etc. IEN institutions can be

8 Scott (1999: 310) argues that "formal order... is always and to some considerable degree parasitic on informal processes, which the formal scheme does not recognize, without which it could not exist, and which it alone cannot create or maintain." 
seen as the result of "human action, but not human design," and are best understood as emergent solutions to the obstacles facing interacting citizens. ${ }^{9}$

2. Indigenously-introduced exogenous (IEX) institutions - IEX institutions are those institutions which are internally developed, but are exogenously introduced. For instance, a national authority may develop institutions at the country level, or a warlord or local power broker may exercise control over a specific area of the country. The resulting economic, political, security, or social institutions are therefore ex ogenously introduced.

3. Foneign-introduced exogenous (FEX) institutions - FEX institutions refer to institutions which are exogenously imposed or developed by foreigners. The many examples of attempts by the international community to engage in state-building to improve or impose political and legal regimes are examples of this category.

In practice-particularly in Afghanistan and the $\mathrm{DRC}$ - there is a large degree of heterogeneity within each category and overlap between these categories of institutions. In Afghanistan, for instance, there is the Afghan National Government as an IEX institution, but provincial governors also exercise a large amount of autonomous rule and control over specific districts and provinces. Further, the Taliban maintains control mainly in the south of the country (at the time of writing). Historically, power brokers like Ismail Khan, Ahmed D ostum, Atta Muhammad Noor, etc. have maintained control over specific areas across the country. Also, there is overlap between FEX/IEX institutions where state collapse/ state failure has taken place, as various international actors have invested significant resources into the development of state institutions. In

\footnotetext{
9 IEN institutions are often damaged throughout the course of war (see, for instance, Del Castillo, 2008: 18-19). North (1990: 3) defines institutions as "... the rules of the game in a society or, more formally, are the humanly devised constraints that shape human interaction. In consequence they structure incentives in human exchange, whether political, social, or economic." Where these humanly devised constraints are absent as a result of conflict and social/ political disorder, state-building efforts are even more challenging. The norms and 'informal institutions' that guide exchange and interpersonal interaction are often damaged in the wake of conflict. Ideological, ethnic, clan-based or religion-based conflict requires the development of local peace-building institutions which are difficult to forge in practice. See, for instance, the chapter on 'normlessness' (i.e. 'anomie') in Afghanistan by G eller (2009).
} 
many cases, IEX institutions are not purely indigenous either, as regional warlords, insurgents, and others who impose institutions in specific regions are often financed by foreign governments or organizations.

While recognizing these overlaps and caveats, the framework above captures several important points about 'institutional stickiness'. For one, it captures Scott's emphasis on the importance of métis for social order. When institutions, reconstruction projects, and counterinsurgency strategies do not align with métis, local incentives, and local preferences, the enforcement costs will be relatively high. This is not to say that local incentives/ preferences are necessarily 'good,' as they can be rather perverse. For instance, members of a local militia may face few binding constraints on their behavior and may expropriate assets, 'tax'-i.e. extort-citizens, and engage in human rights abuses. Imposing constraints or changing incentives requires some function of diplomacy, legal pressure, political/financial incentives, or military/ police force. However, where these local incentives and preferences are not aligned with the Afghan or Congolese constitutions, the costs of enforcement will rise.

\section{State Building as High Modemism}

Fukuyama (2004: ix) defines state-building as "the creation of new government institutions and the strengthening of existing ones." State-building efforts are often undertaken with the end goals of “... an elected executive and legislature, a rules-based bureaucracy, an independent judiciary, a security apparatus under civilian control, and a regulated market economy-in short, effective, accountable public institutions that can support a broad range of civil, political, economic, and social rights" (ID S 2010: 1). While these state-building goals may be ideal in the abstract, there are 
significant challenges associated with reaching them in practice. As discussed above, efforts to reform or implement state institutions- e.g. formal constitutions, democratic elections, national and regional police forces, etc.- result in significant enforcement costs if these institutions are not aligned with the underlying métis at the local level. This may be because sub-national non-state political actors have interests of their own (territorial control, ideology, wealth, etc.) or because those involved with the development of such institutions were not aware of the beliefs and preferences of citizens.

The lack of attention to context-specific knowledge and local incentives may help to explain why most post-conflict reconstruction and state-building efforts have been much more difficult in practice than in theory. As put in a 2010 Institute of Development Studies (ID S) report, "building effective, accountable formal institutions in poor countries has proved much harder than many people expected. Experience suggests that 'skipping straight to Weber' will not work" (2010: 7). Developing state institutions requires the tools of diplomacy, the provision of financial/political incentives, the use of military/ police force, and legal pressure- e.g. referrals to the International Criminal Court at The Hague or the use of local courts and legal procedures to enforce justice. These processes take a significant amount of time, resources, and trial-and-error from those involved in state-building processes. Further, state builders often face perverse incentives and imperfect, or altogether missing, feedback loops to make the necessary adjustments.

To provide a more concrete example of 'high modernism' in state-building, Autesserre (2010: 3) describes efforts to improve central institutions in the D RC as such:

Foreign donors contributed more than half of the Congolese national budget. They impelled Congolese warlords through the official reunification of the country, the formation of a unified government, the preparation for democratic elections, and the progressive integration of the different armed groups into a single national army. They closely supervised the legislative, constitutional, and electoral processes. They 
ensured that the candidate they viewed as most able to maintain stability, President Joseph Kabila, was in the best possible position to win the elections. They made certain that troops from neighboring countries officially remained out of Congolese territory. In many places, the UN peacekeeping mission was the only force protecting the population against the remaining armed militias. During these three and a half years, the international influence was so large that numerous Congolese political leaders, international actors, and journalists equated the Congolese situation to a "protectorate."

While these state-building efforts may have sounded optimal in the abstract, the underlying role of métis went largely underappreciated, particularly with regard to local political operating rules and incentives. Because many of the conflicts in the D RC have local origins, the development of political institutions at the central level, as opposed to the development of institutions of conflict resolution and community development at the local level, neglected the root of the problem. Autesserre (2010: 6) argues that "local agendas - at the level of the individual, the family, the clan, the municipality, the community, the district, or the ethnic group-at least partly drive the continuation of violence during peace agreement implementation.. ${ }^{10}$ The current conflicts in the eastern provinces of the D RC provide further evidence the failure of state-building efforts to date. For example, instead of spending millions of dollars on holding elections at the national level, perhaps these resources would have been better allocated to processes aimed at developing lower-level peace-building institutions or processes aimed at bringing government troops, rebel groups like the FDLR, and Mai Mai militias under control. ${ }^{11}$

As a perfect illustration of the insights in both of Scott's books, local conflicts were often viewed by foreign interveners as "the result of insufficient state authority and of the Congolese people's

\footnotetext{
${ }^{10}$ Autesserre (2010) further argues that many of the stalled transitions to peace in post-conflict settings like South Africa, Burundi, and Kosovo were rooted in local agendas (e.g. power struggles within local political parties) that led to further violence.

11 Jason Stearns (2011b), the former Coordinator of the United Nations Group of Experts on the Congo, argues the following: "Perhaps most worrisome is the state's persistent weakness. The national army-more than 50,000-strong in the east alone-is weak and abusive at the same time, unable to suppress rebellions on the one hand, and unwilling to discipline its own abusive soldiers on the other. Elections did not bring peace or development."
} 
inherent propensity to violenœ" (Autesserre 2010: 11, italics added). Those involved in state-building processes in the DRC paid more attention to meta-level factors like the holding of elections, the development and improvement of the security sector, and the bolstering of the Kinshasa government rather than addressing the causes (and consequences) of localized conflict.

There are also bureaucratic and cultural aspects of state-building processes related to the 'high modernism' identified in Seeing L ike a State. For instance, a local peacebuilder remarked to Autesserre (2010: 84) that "there is a tendency for foreign interveners at different levels to arrive with their baggage, their methodology; sometimes they call it their 'toolkit."' Consider the case of Afghanistan. In early 2010, the U.S. military led an operation in Marja aimed at displacing the Taliban. A 'government in a box' strategy was employed, whereby the military operation was quickly followed by the provision of security, health, education, and labor market services in order to win the 'hearts and minds' of Afghans in the district (Norland 2010). Similarly, in the Congo, Autesserre (2010: 84) remarks that the problems of the government transition were approached "... through a series of standardized, technical tasks." Instead of allowing representatives of local populations to drive state-building or peace-building efforts, a top-down reliance on blueprints for institutional and economic development is unlikely to be successful for the reasons identified in Scott's works.

A lack of understanding of the importance of métis may also explain why corruption levels in Afghanistan are so high. The international community provides a significant amount of funds to the Afghan government, local contractors, etc. without an understanding of how these funds will be used in practice because those receiving the funds are largely nontransparent and unaccountable for their actions. While increasing the level of resources devoted to security, health, education, etc. may work in other contexts, because of the form of underlying métis in Afghanistan, this has ostensibly been less effective. Where 'cultures of corruption' or 'cultures of war' have taken place, changing the 
underlying forms of 'how things get done' is a very complex task constrained not just by resources, but more importantly by a lack of knowledge by outsiders of how to design superior institutions.

Because state-building efforts have not been effective in Afghanistan and the D RC, in some cases local political actors- e.g. politicians, 'local power brokers,' etc.- as well as ideological insurgents- e.g. the Taliban, Hezb-i-Islami, the Haqqani network, al Q aeda, etc. in Afghanistanhave emerged to fill the security void. In other cases, the emergence of local militias has been actively encouraged by the central government and state builders (particularly by NATO-ISAF in Afghanistan) as a means to shore up security. The increased reliance on local militias by state builders highlights the challenges with regard to the knowledge problems associated with centralizing power in a manner which allows the national government to effectively control all of Afghanistan. ${ }^{12}$ The U.S. military, for instance, has been training village-level security groups to fight against insurgents like the Taliban (Chandrasekaran 2010). Importantly, these efforts at improving local security can undermine efforts to improve the institutions of the nation state.

Yet local agendas further add to the complexity of the situation, making it difficult for outsiders to prevent conflict or develop community-level institutions that try to incorporate disparate parties. For example, indigenous militias- e.g., the Mai Mai-in the DRC organized initially to protect local communities, but "... quickly started using their military might to abuse their own communities, seize land and mining sites, or capture political power" (Autesserre 2010: 7). Similarly, the Arbakai in Afghanistan have also been known to 'tax' and abuse the local population (Rubin 2010b; Mashal 2011). Without effective constraints on local political groups and warlords,

\footnotetext{
${ }_{12}$ Much like recent efforts to expand the role of the state in Afghanistan, the Soviet-backed Karmal regime of the 1980s relied heavily on militias to project its authority across the entire country (Giustozzi 2009). There were a number of limitations to this strategy, including the risk of rebellion against the Karmal regime, fewer candidates for regular military forces, and the "increasing autonomy and undisciplined behaviour of many militias" (Giustozzi 2009: 55). These limitations still apply to current efforts to expand the presence of the Afghan state (see, for instance, Chandrasekaran 2010; IRIN 2010; Jaffe and Chandrasekaran 2010; Mashal 2010; Rubin 2010b; IRIN 2011; Shah 2011).
} 
'local empowerment' may actually undermine the broader goals of state-building. This is especially the case when they maintain control of specific regions with the associated tax revenues and political power. ${ }^{13}$

\section{State Building and The Art of Not Being Governed}

In The A rt of $\mathrm{N}$ ot Being $\mathrm{G}$ overned, Scott discusses how state-building efforts in Zomia were often resisted by indigenous populations and specific insurgent groups. Further, Scott highlights how these groups were often able to develop effective forms of self-governance in the absence of state authority. We explore some of these themes in the sub-sections below. In Afghanistan and the DRC, there are sub-national armed actors that resist the expansion of state institutions. Further, there are a number of civil society and customary organizations that have partially filled the void in governance (particularly with regard to the provision of traditional public goods and services, though less so for regional security). We first discuss the roles played by some of these organizations as well as their limitations. We then assess the implications of state resistance as identified by Scott in The A rt of $\mathrm{N}$ ot Being $\mathrm{G}$ overned by sub-national armed actors for state-building processes.

\subsection{Self-Govemance and State Building}

Brick (2008: 2) explains how three informal organizations (shuras [village councils], maliks [village executives], and mullahs [village lawgivers]) "emerged before a central state consolidated" implying that their "existence is thus exogenous to the state," and therefore may play productive roles in

${ }^{13}$ See D el Castillo (2008: 166-174). 
state-building efforts in Afghanistan. While there are important limitations to these organizations as substitutes (or complements) for state capacity (such as the development or promotion of regional security) there is by no means a tabula rasa in many of these countries when it comes to providing public goods and local conflict resolution (see Murtazashvili 2009). ${ }^{14}$

Where there is weak state capacity or state collapse, informal civil society or local governance organizations often fill the void to perform many state functions. ${ }^{15}$ Relative to the dysfunctional state, these alternatives, while imperfect, are often superior. In the context of state collapse in the DRC, for instance, Seay (2009: 13) finds that "non-state actors often serve as the creators and maintainers of social order in what would otherwise be chaotic urban zones." Many of these nonstate actors/ civil society organizations include churches. She argues that "the eastern D.R. Congo is a fascinating example of what governance without government looks like, and of how groups of people organize authority and maintain institutions for themselves when a state does not" (2009: 46). ${ }^{16}$ Murtazashvili (2009: 2) argues that "customary organizations in Afghanistan have a number of institutional features that facilitate local governance that can serve as a source of state capacity." Even with weak central state capacity, there is not 'lawlessness' at the village level. Indeed, "villages are well governed through informal rules and norms based on social norms that mediate daily life and constrain the actions of villagers through customary forms of rewards and sanctions" (2009: 3).

\footnotetext{
${ }^{14}$ Efforts to build up the power of the central state over time have neglected or repressed these informal governance organizations. Brick (2008: 6) describes how "In the 1970s, the government of D aud K han tried to co-opt many of them into the formal government. In the 1980s, the Communist government tried to eliminate them as agents of feudalism and backwardness... various warlords, governments, and political parties in the 1990s understood the importance of these organizations and sought to dominate them by populating them with their own agents."

${ }^{15}$ As we consider below, however, rebel groups and insurgents like the Taliban also fill this void.

${ }^{16}$ Yet Seay (2009: 59) also recognizes some of the shortcomings of these organizations for fulfilling the proper roles of the state, describing how after the collapse of the state, "government institutions ceased to function as agents of the state, the state lost its ability to adequately regulate the activity of hospitals and schools that were under the management of churches, and the judiciary ceased to function without the payment of bribes. Infrastructure management was abandoned, the jungle grew back over roads and rail lines that served as the only shipping routes for huge swaths of the country's southeast, boats ceased to carry goods and people along the Congo and Kasai rivers, and police and the army were completely incapable of providing even the most basic levels of security. Life for many Congolese became quite miserable and short. An estimated 5.4 million people have died of war-related causes since 1998."
} 
While remarkably heterogeneous, some warlords often provide traditional public goods, such as security, in Afghanistan (Giustozzi 2005), though others have been known to kill innocent civilians and commit atrocious human rights abuses. ${ }^{17}$

In the D RC, Seay (2009: 3) discusses how "civil society organizations substitute for the state in almost every aspect of public goods provision present in the [eastern D RC]." As she describes, "civil society organizations in the eastern Congo in many ways function as the state, by operating institutions, managing disputes, collecting user fees in lieu of taxes, hiring personnel (who are often technically state employees, but who are actually hired and paid by the civil society organization), providing security, and maintaining a basic level of public order" (2009: 9). Afoaku (2007: 7) describes how "like many African countries, post-conflict Congo has limited capacity to respond to the country's staggering governance challenges. This situation, coupled with donor pressure, has served as a catalyst to the growth of the civil society sector, with thousands of local and international NG Os emerging over the past decade to provide critical services in place of the state."

While perhaps effective at providing what many economists consider to be traditional 'public goods' and raising revenues, local governance organizations may not help to solve the larger political 'meta-games' that take place in such places as Afghanistan and the DRC. These local governance organizations were present during the civil wars and civil conflicts that took place (and are currently taking place) in these countries. While perhaps crucial for the provision of local goods and services,

17 In Afghanistan, for instance, Giustozzi's (2005: 7) field work suggests that "at least some warlords tried to institutionalise what used to be looting and plundering and transform it into something akin to a regular taxation." He further argues that "in such cases it could be argued that warlords are not necessarily worse predators than states themselves, not only because they may provide a few social services and infrastructure, but most of all because security from external threats, which in some cases warlords genuinely offer, is also a very important service. Forms of patronage, such as the creation of redundant militia units, can also be seen as services by sections of the population (a sort of unemployment benefit) and therefore contribute some legitimacy to the warlords, possibly more effective than some low-quality education or health system. At least from a heuristic point of view, it looks more appropriate to think in terms of a confrontation of different forces, all intent on raising revenue and all defending/ promoting some particular alignment of social groups or coalition of individuals, rather than write some of the players (the warlords) off as 'bandits' and 'criminals'." 
they were rather ineffective in projecting their power over broader regions to ensure security. ${ }^{18}$ Ending conflict may require some form of professional regional-level security institutions (e.g. military, police, etc.) as opposed to local-level security institutions. In an ideal world, the development of professional security forces at all levels of government (e.g. national, district/ province, village/ local, etc.) would take place and align. As Giustozzi (2010: 100) argues, "a key challenge is the development of a local but disciplined military force (gendarmerie), as opposed to being a patrimonial para-military force under the control of a local strongman." However, in practice this has been difficult to accomplish and highlights one of the significant challenges of statebuilding. There are often fluid relations between state militaries and police forces and sub-national non-state political actors (Afoaku 2007) in the D RC. This is perhaps best-documented in the case of Colombia, where there are strong ties between the Colombian military and paramilitary groups across the country (see D ube and Naidu 2007).

Yet alongside civil society and customary organizations, rebel groups and ideological organizations like the Taliban fill the governance voids in these countries. In Afghanistan, where the central state has been absent, the Taliban has been able to develop systems of local governance. Indeed, the Center for Strategic and International Studies reports that "insurgents now have shadow governments in every province but Kabul; [they] have active influence in more districts than [the] Afghan government" (Cordesman 2011: 28). In the D RC, rebel groups and local militias have been able to operate with complete impunity (particularly in the eastern provinces of the country) because of state absence.

\footnotetext{
18 See Schetter et al. (2007: 144; 150). Further, as noted by Afoaku (2007), civil society organizations face a number of limitations from the national and local governments in the Democratic Republic of the Congo. For instance, Afoaku (2007: 7) notes that "both national and provincial-level officials at times forcibly restrict civil society activists from performing their work. Rights activists are at particularly high risk of arrest, threats, and attacks, especially if their denunciations involve security force actors."
} 


\subsection{State Resistance}

Afghanistan's history is replete with examples of resistance to efforts to expand the central state (either from internal or external political actors). Contemporary state building in Afghanistan is particularly daunting, especially since Giustozzi (2009: 91) reports that, "according to official estimates, which certainly overlooked many of the groups, there were 2,753 'illegal armed groups', numbering some 180,000 armed men, in 2006." ${ }^{19}$ State-building therefore ultimately requires coopting these armed groups to ensure that the central government has a monopoly on the legitimate use of force across the entire country. However, coordinating this process and ensuring appropriate constraints on those with monopoly on force is a very costly and difficult endeavor. Without the appropriate checks in place, monopolizing force could potentially lead to a worse outcome then decentralized conflict.

Armed rebellion or insurgency is the most violent manifestation of the desire to not be governed by a central authority. In Afghanistan, tribal rebellions against imperial expansion have occurred throughout the country's history. In modern day examples of state-building, where there are efforts to expand the role of the state and extend into lawless regions, there are also groups that resist this expansion. Postcolonial lowland states sought to exercise their authority in Zomia through the use of "military occupation, by campaigns against shifting cultivation, by forced settlements by promoting the migration of lowlanders to the hills, by efforts at religious conversion, by spaceconquering roads, bridges, and telephone lines, and by development schemes that project government administration and lowland cultural styles into the hills" (Scott 2009: 20). This is

\footnotetext{
${ }^{19}$ Consider that Giustozzi (2009: 95) reports that "[Abdul Rashid] D ostum, Ismail Khan and the north-eastern Jami'atis all tried to resist the pressure of the central government. Increasingly constrained in the use of armed force by the deployment of foreign troops in the provinces and by growing international scrutiny, they developed grassroots support structures which were used in public demonstrations and rioting, probably succeeding in slowing down their gradual marginalization and achieving some legitimization by participation. But they could not completely halt the process and Kabul's centralization efforts certainly weakened the warlords."
} 
somewhat analogous to state-building efforts in Afghanistan, where NATO-ISAF assists the central Afghan state in countering particular political organizations/ insurgents- e.g., the Taliban, the Haqqani network, Al-Q aeda, Hezb-i-Islami-through the use of military force, where different crops are substituted for opium production, and where development projects are heavily promoted and financed at the national, city, and tribal levels.

Yet there are also forms of non-violent resistance to state-building efforts- e.g. corruption, tax evasion, etc. Some state political actors may also seek to minimize the degree to which state institutions act as binding constraints on their behavior (see Stearns 2011a, b, in the context of the D RC). Perhaps naturally, efforts to develop effective tax administrations will face resistance and tax evasion. Consider that Giustozzi (2009: 39) describes how in Afghanistan, "the landed wealth of Herat's elites was the main source of their power and much of their effort to secure local autonomy might be explained by their desire to protect it from central taxation. The city had a tradition of rebelling against the dominant power, particularly when the local balance of power was being upset, and of demands for self-rule." Warlords in Afghanistan are hesitant to share tax revenues with the national government as this poses a challenge to their authority and control over specific areas of the country (see Del Castillo 2008; Giustozzi 2009). There are also areas in Afghanistan where citizens actively avoid state-making projects (see West 2011).

One of the most profound implications of Scott's The A rt of N ot Being G overned for current state-building efforts is that populations in specific regions or political actors/ organizations are capable of resisting the expansion of the state for a long period of time. This implies that state building can take significant periods of time, if it ever happens at all. O ne thing that Scott forces us to realize is that we cannot assume that citizens want a central state where it doesn't exist. Further 
there is evidence to indicate that 'outsiders' don't know how to go about building an effective state even if citizens do want such institutions (see Bueno de Mesquita and D owns 2006; Coyne 2007).

In Seeing L ike a State, Scott (1998: 345) suggests that taking small steps, favoring reversibility, planning on surprises, and planning on human inventiveness are potential ways to avoid disasters in development planning. Scott describes that "in an experimental approach to social change, presume that we cannot know the consequences of our interventions in advance. Given this postulate of ignorance, prefer wherever possible to take a small step, stand back, observe, and then plan the next small move" (Scott 1998: 345). Instead of overarching plans for state-building efforts, seeing what works in development requires a flexible, piecemeal, perhaps even 'trial and error' approach (while doing no harm) to state-building and peace-building (see E asterly 2006). ${ }^{20}$ Along similar lines, Hayek (1988) argued that the "extended order" of human society was largely a spontaneous order which was the result of purposeful human action, but not human design. This view contrasts sharply with centrally-planned efforts to build the state, either at the national or local levels.

As a concrete example, Beath, Christia, and Enikolopov (2010) find that in Afghanistan, the National Solidarity Programme (NSP) - a community-driven aid program administered by the Ministry of Rural Rehabilitation and Development with funding from an array of donors- led to improvements in attitudes among Afghan civilians towards the government. They conclude that in the process of state-building, the NSP can provide legitimacy to the central government. However, they find no evidence for an effect of the program on the level of violence in Afghanistan, which suggests that solving the 'meta-game' of counterinsurgency and state-building may be an elusive goal. Coyne (2006, 2007) highlights the knowledge constraints associated with designing and

${ }^{20}$ However, there is another side to this as well, as changes in policy and programs may result in considerable regime uncertainty (see Coyne and Pellillo forthcoming a, forthcoming b). 
implementing a solution to the meta-game and associated nested games which characterize many efforts and state building.

Scott concludes Seeing Like a State (1998: 353) by arguing the following: "Without denying the incontestable benefits either of the division of labor or of hierarchical coordination for some tasks, I want to make a case for institutions that are instead multifunctional, plastic, diverse, and adaptable-in other words, institutions that are powerfully shaped by métis," which sharply “... contrasts the fragility of rigid, single-purpose, centralized institutions to the adaptability of more flexible, multipurpose, decentralized social forms" (353-354). This would be good advice for both those currently engaged in state-building efforts, as well as for those who are considering such efforts. It implies that there are constraints on what can be designed and implemented even when such efforts are driven by the best of intentions. These constraints include the feasible institutional alternatives, which are constrained by existing métis, as well as the ability of outsiders to grasp and understand these alternatives given their distances from this context-specific knowledge.

\section{Conclusion}

Our goal in this paper has been to explore some of the implications of James Scott's Seeing L ike a State and The A rt of N ot Being G overned for state-building efforts in Afghanistan and the DRC. There are three as follows.

First, where state-building efforts are incompatible with the underlying beliefs and incentives facing citizens and political actors, there will be significant enforcement costs associated with statebuilding. In essence, one cannot impose institutions and assume they will necessarily 'stick'. Individuals respond to the incentives they face and if these incentives are not aligned with the 
institutions that are imposed or reformed, then there will be high costs of enforcing these institutions. $^{21}$

Second, one of Scott's (2009) key insights is that efforts to expand the state may be met with persistent armed resistance or strategic avoidance. From a policy perspective, this implies that efforts to expand the institutions of the central state in Afghanistan and the D RC will likely be met by violent resistance by sub-national non-state political actors/ organizations. Where violent resistance is not met, the costs of developing and implementing new institutions will still be high because of the need to co-opt these sub-national non-state political actors/ organizations. Finding a match between the formal institutions of the state and the underlying métis, preferences, and political incentives is difficult precisely because of the knowledge constraints facing state builders. As in Colombia, it may be the case that what emerges in Afghanistan and the DRC may be an uneasy coexistence between the central government and sub-national non-state political actors may emerge

Finally, a key implication of The A rt of $\mathrm{N}$ ot Being $\mathrm{G}$ overned is that citizens in foreign societies may resist state building because they do not desire a strong central state. As discussed, there are many historical cases of citizens rejecting state-building efforts for significant periods of time. As highlighted by the previous implication, where such tendencies exist, state building will be relatively costly and difficult. However, another implication is that where citizens do not want a central state, efforts at state building can actually make citizens significantly worse off. By imposing institutions on people who do not want them, state builders by definition are making citizens worse off, at least

\footnotetext{
${ }^{21}$ In a recent article, Acemoglu et al. (2009) argue against this position. They contend that the impact of the French Revolution on European institutions proves that good institutions can be imposed from outside. Specifically, after 1792, French forces invaded numerous countries and imposed a civil code while abolishing guilds and the remnants of feudalism. They argue that the countries invaded performed better economically than those that didn't. This, however, misses the point. The use of the guillotine is a means of raising the cost of enforcement. D emand curves do indeed slope downward and if you raise the cost of certain behaviors high enough people will respond. Stated simply, if the gun is big enough outsiders can get insiders to behave differently. Putting aside the issue of ethics, this is an extremely costly means of changing behaviors.
} 
at the time of imposition. Moreover, unless state-building creates appropriate constraints on government, a task which has proven difficult in the past, then state building can result in the unconstrained centralization of force, which imposes significant harms on citizens who did not desire such centralization in the first place.

This final implication highlights that state-building is not simply a matter of resources or effort, but also an issue of whose preferences are prioritized. State builders may be motivated by the best of intentions, but if they provide something that citizens do not want it is unclear how they have made them better off. One could argue that state builders are somehow 'enlightened,' but Scott's Seeing Like a State calls this assumption into question by providing evidence of an array of failures based on well-intentioned central planning. Moreover, a key theme of The A rt of N ot Being Governed is that the hill people are not irrational, but instead rationally choose to exit the reaches of the predatory state. If we assume that people are in the best position to know what they want, then it cannot be assumed that state building is the preferable course of actions. Taken together, the central lessons in Seeing Like a State and The A rt of $\mathrm{N}$ ot Being $\mathrm{G}$ overned have radical implications for debates and discussions on both the desirability and feasibility of state-building efforts. 


\section{References}

Acemoglu, D ., Cantoni, D., Johnson, S., and Robinson, J.A. (2009). The Consequences of Radical Reform: The French Revolution. NBER Working paper \#14831.

Afoaku, O. (2007). Democratic Republic of the Congo. Africa Research Bulletin: Economic, Financial and Technical Series, 44(2), 17289A-17290C.

Autesserre, S. (2010). The Trouble With the Congo: Local Violence and the Failure of International Peacebuilding. Cambridge, MA: Cambridge University Press.

Baird, M. (2010). Service Delivery in Fragile and Conflict-Affected States. World Bank World D evelopment Report 2011 Background Paper.

Beath, A., Christia, F., and Enikolopov, R. (2010). Winning Hearts and Minds? Evidence from a Field Experiment in Afghanistan. Working paper.

Boettke, P.J., Coyne, C.J., and Leeson, P.T. (2008). Institutional Stickiness and the New D evelopment Economics. A merican Journal of E conomics and Sociology, 67(2), 331-358.

Brick, J. (2008). "The Political Economy of Customary Village Organizations in Rural Afghanistan.” Working paper, presented at the Annual Meeting of the Central Eurasian Studies Society, Washington, D C, September 2008.

Bueno de Mesquita, B. and Downs, G.W. (2006). Intervention and Democracy. International O rganization, 60(3), 627-649.

Chandrasekaran, R. (2010). U.S. Training Afghan Villagers to Fight the Taliban. Washington Post, April 27.

Chowdhury, Arjun and Ronald R. Krebs. (2010). "The Afghan Challenge is Far Tougher." In the symposium "Après Louis, Hamid Subtitle: Can Afghan State Builders Learn From Louis XIV?" Foreign Affairs, 89(4).

Cordesman, Anthony. (2011). "Afghanistan and the Uncertain Metrics of Progress: Part One: The Failures that Shaped Today's War." Center for Strategic and International Studies. February 15, 2011 Report.

Coyne, C.J. 2006. Reconstructing Weak and Failed States: Foreign Intervention and the Nirvana Fallacy. Foreign Policy Analysis, 2, 343-361.

Coyne, C.J. 2007. After War: The Political Economy of Exporting Democracy. Stanford, CA: Stanford University Press.

Coyne, C.J., and Pellillo, A. (Forthcoming a) Economic Reconstruction Amidst Conflict: Insights from Afghanistan and Iraq. D efence and Peace Economics.

Coyne, C.J. and Pellillo, A. (Forthcoming b). The Political Economy of War and Peace. In W.F. Shughart, L. Razzolini, M. Reksulak (Eds.), The Elgar Companion to Public Choice, Second Edition. New York: Edward Elgar. 
Del Castillo, G. (2008). Rebuilding War-Torn States: The Challenge of Post-Conflict Economic Reconstruction. Oxford: Oxford University Press.

Dube, O., and Naidu, S. (2010). Bases, Bullets, and Ballots: The Effect of U.S. Military Aid on Political Conflict in Colombia. Center for Global D evelopment Working Paper \#197.

Easterly, W. (2006). The White Man's Burden. New York, NY: Penguin Press.

Filkins, D . (2010a). With U.S. Aid, Warlord Builds Afghan Empire. New York Times, June 5.

Filkins, D . (2010b). Convoy Guards in Afghanistan Face an Inquiry. New York Times, June 6.

Fukuyama, F. (2004). State-building: Governance and World O rder in the $21^{\text {st }}$ Century. Ithaca, NY: Cornell University Press.

Gall, C. (2010). In Afghanistan's North, Ex-Warlord Offers Security. New York Times, May 17.

Geller, Armando. (2010). "The Political Economy of Normlessness in Afghanistan." In Ceri Oeppen and Angela Schlenkhoff (eds.), Beyond the Wild Tribes: Understanding Modern A fghanistan and Its D iaspora. New Y ork: Columbia University Press.

Giustozzi, Antonio (2005). "The Debate on Warlordism: The Importance of Military Legitimacy." London School of Economics Crisis States Research Centre, Discussion Paper No. 13.

Giustozzi, Antonio (2009). E mpires of Mud: W ar and W arlords in A fghanistan. New York: Columbia University Press.

Giustozzi, Antonio (2010). "Dilemmas of G overnance in Afghanistan: Between Patrimonialism and Bureaucratisation." In Ceri O eppen and Angela Schlenkhoff (eds.), Beyond the W ild Tribes: Understanding M odern A fghanistan and its D iaspora. New York: Columbia University Press, pp. 89-102.

Hayek, F.A. (1988). The Fatal Conceit: The Errors of Socialism. Chicago, IL: The University of Chicago Press.

Institute of D evelopment Studies. (2010). An Upside-down View of Governance. Available online: http:// www2.ids.ac.uk/ gdr/ cfs/ pdfs/ AnUpside-downViewofG overnance.pdf. Accessed on 23 March 2011.

IRIN. (2010). AFGHANISTAN: NGO s Call on NATO, Afghan Government to Stop Using Local Militas. November 19.

IRIN. (2011). AFG HANISTAN: Fears Over Child Recruitment, Abuse by Pro-Government Militias. January 20.

Jaffe, G. and Chandrasekaran, R. (2010). U.S. Ambassador Puts Brakes on Plan to Utilize Afghan Militias Against Taliban. Washington Post, January 22.

Kalyvas, S. (2006). The Logic of Violence in Civil War. New York, NY: Cambridge University Press. 
Lyall, J. and Wilson, I. (2009). Rage Against the Machines: Explaining Outcomes in Counterinsurgency Wars. International O rganization, 63(1), 67-106.

Mashal, M. (2011). Rogue Militias Abuse Rural Afghans. Al Jazeera, January 12.

Murtazashvili, J.B. (2009). The Microfoundations of State Building: Informal Institutions and Local Public G oods in Rural Afghanistan. D issertation, University of Wisconsin-Madison.

Nordland, R. (2010). U.N. Rejects 'Militarization' of Afghan Aid. N ew Y ork Times, February 17.

North, D.C. (1990). Institutions, Institutional Change, and Economic Performance. Cambridge, MA: Cambridge University Press.

Ottaway, M. (2002). Nation Building. Foreign Policy, 132, 16-24.

Rubin, A.J. (2010). Taliban Extend Reach to North, Where Armed Groups Reign. New York Times, D ecember 15.

Seay, L. (2009). A uthority at Twilight: Civil Society, Social Servioes, and the State in the E astern D emocratic Republic of the C ongo. Dissertation, University of Texas at Austin.

Schetter, C., Glassner, R. and Karokhail, M. (2007) Beyond Warlordism. The Local Security Architecture in Afghanistan. Internationale Politik und Gesellschaft: 136-152. Available at: http:// www.fes.de/ ipg/ inhalt d/ pdf/ 10 Schetter US.pdf. Accessed 3 March 2011.

Scott, J. C. (1998). Seeing Like a State: How Certain Schemes to Improve the Human Condition Have Failed. New Haven, CT: Y ale University Press.

Scott, J.C. (2009). The Art of Not Being G overned: An Anarchist History of Upland Southeast Asia. New Haven, CT: Yale University Press.

Shah, A. (2011). Afghan Underworld Shows Challenges for Stability. Associated Press, January 18.

Skarbek, D .B. and Leeson, P.T. 2009. What Can Aid D o? Cato Journal, 29(3), 391-397.

Stearns, J. (2011a). Elections in D RC are an Imperfect but Necessary Step Towards Order. The G uardian, PovertyMatters Blog, January 19.

Stearns, J. (2011b). Dancing in the Glory of Monsters: The Collapse of the Congo and the Great War of Africa. New York, NY: PublicAffairs.

Steinberg, G., and Wormer, N. (2010). Escalation in the Kunduz Region. SWP Comments, German Institute for International and Security Affairs. Available at http:// www.humansecuritygateway.com/ documents/ SWP EscalationintheK unduzRegion WhoAretheInsurgentsinNortheasternAfghanistan.pdf. Assessed 23 March 2011.

Tilly, C. (1975). Reflections on the History of European State-Making. In C. Tilly (Ed.), The Formation of National States in Western Europe, (pp. 3-83). Princeton, NJ: Princeton University Press.

Tyson, A.S. (2008). New Joint Effort Aims to Empower Afghan Tribes to Guard Themselves. Washington Post, March 31. 
Van de Walle, S., and Scott, Z. (2009). The Role of Public Services in State- and Nation-Building: Exploring Lessons from European History for Fragile States. G SD RC Research Paper.

Weber, M. (1948). From Max Weber. Translated by H. H. Gerth and C. W. Mills. New York, NY: Galaxy.

West, B. (2011). The Wrong War: Grit, Strategy, and the Way out of Afghanistan. New York, NY: Random House.

Widner, J.A. (1995). States and Statelessness in Late Twentieth-Century Africa. Daedalus, 124(3), 129-153.

Williamson, C.R. (2010). Exploring the Failure of Foreign Aid: The Role of Incentives and Information. The Review of Austrian Economics, 23(1), 17-33. 